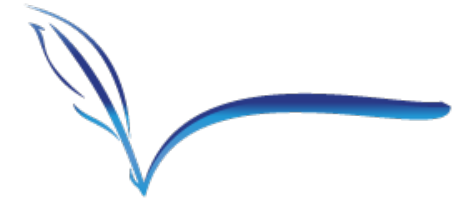

SSAD

Stratejik ve Sosyal Araştırmalar Dergisi

ISSN 2587-2621

Cilt 5, Türk-Yunan İlişkileri Özel Sayısı | Volume 5, Special Issue: Turkish-Greek Relations, 30 Ağustos/30 August 2021 sisaddergi@gmail.com

Makale Türü/Article Type: Araştırma/Research

Makale Gönderim Tarihi/Received Date: 05.06.2021

Makale Kabul Tarihi/Accepted Date: 12.07.2021

DOI: $10.30692 /$ sisad.948284

\title{
RETHINKING LIMITS OF ANTI-MUSLIM HATRED AND DISCRIMINATION IN CONTEMPORARY GREECE*
}

\section{Günümüz Yunanistan'ında Müslüman Karşıtı Nefret ve Ayrımcılı̆̆ı Yeniden Düşünmek}

\author{
Ali HÜSEYINOĞLU \\ Doç. Dr. \\ Trakya Üniversitesi \\ Balkan Araştırma Enstitüsü \\ ORCID ID: 0000-0002-2101-217X \\ alihuseyinoglu@trakya.edu.tr
}

\begin{abstract}
Atıf/Citation: Ali Hüseyinoğlu (2021), "Rethinking Limits of Anti-Muslim Hatred and Discrimination in Contemporary Greece”, Stratejik ve Sosyal Araştırmalar Dergisi Türk Yunan İlişkileri Özel Sayısı, C. 5, 30 Ağustos 2021, s.1-20.
\end{abstract}

\begin{abstract}
There has been a growing academic literature about Islam in the West since 9/11 while Islam per se is actually an old phenomenon in the continent of Europe. Even if Muslims enjoy a variety of religious rights, Islamophobia is on rise all over Europe. In this respect, this study takes Greece as a case study and analyzes to what extent Islam has been incorporated in Greece. While doing so, it dwells both on historical and new Muslim groups so as to find answers to two primary questions. First, to what extent does Greece respect rights of Muslims residing in different parts of the country? Second, what does Islamophobia mean in the context of Greece? Doing so, this study argues that Greece has never allowed enjoyment of Muslims' freedoms in full terms since its establishment as of this day. Rather, it has chosen to penetrate in their internal affairs via different ways, gradually limit their religious liberties and finally have the ultimate control over fundamental issues of Islam and Muslims living across the country. Moreover, Greece never applied for an establishment of an effective mechanism aiming to fight against anti-Muslim behavior depicted overtly or covertly by those belonging to different segments of the Greek society.
\end{abstract}

Keywords: Greece, Muslims, Islamophobia, religious freedoms, integration.

Öz: 11 Eylül sonrası dönemde İslam ile ilgili Batı'daki akademik literatürde önemli bir artış söz konusudur. Özü itibarıyla İslam aslında Avrupa kıtasında tarihi bir olgudur. Avrupa'da yaşayan Müslümanlar birçok dini özgürlüklerden faydalanıyor olsalar dahi tüm Avrupa çapında İslamofobi yükseliştedir. Bu bağlamda çalışma, Yunanistan'daki İslam olgusunu farklı yönleriyle analiz etmeyi amaçlamaktadır. Bu sebeple tarihi ve nispeten daha yeni oluşmuş Müslüman grupları üzerinde durmakta ve bunu yapmakla iki temel soruya yanıt aramaktadır: Birincisi, ülkenin farklı yerlerinde yaşayan Müslümanların haklarıyla ilgili olarak Yunanistan bu haklara ne denli sayg1 göstermektedir? İkincisi ise Yunanistan özelinde İslamofobi nerede durmakta, ne anlam ifade etmektedir? Bu sorulara

\footnotetext{
* This is the revised and updated version of the article publised as: Huseyinoglu, A. 2015. Questioning Islamophobia in the Context of Greece. IRCICA Journal: A Journal on Islamic History and Civilization, 3 (6), Fall, 65-95.
} 
aranan cevaplar ışığında çalışmanın ortaya koydu temel argüman şudur: Kurulduğu günden günümüze Yunanistan, toprakları üzerinde yaşadığı Müslümanların dini özgürlüklerden tam anlamıyla faydalanmalarına hiçbir zaman izin vermemiştir. Tam tersine, onları ilgilendiren dini konulara farklı yollarla müdahale etmiş, onların dini özgürlüklerini zaman içerisinde kısıtlamış ve sonunda Müslümanları ilgilendiren temel konularda mutlak kontrolü sağlamıştır. Bunun yanında Yunanistan, toplumun farklı kesimlerinden ve ülkenin farklı noktalarından yükselen İslam karşıtlı̆̆ davranışları ile mücadele bağlamında etkin bir mekanizma geliştirmeme adına herhangi bir adım atmamıştır.

Anahtar Kelimeler: Yunanistan, Müslümanlar, İslamofobi, dini özgürlükler, entegrasyon.

\section{INTRODUCTION}

Depending on the context, the term Islamophobia means any type of hatred, discrimination, intolerance, fear or bias towards Muslims. Compared to other versions of religious phobias, it is a relatively new concept used in different disciplines of social sciences. From a Eurocentric perspective, even if there used to be changing modes of fear and discomfort towards the historical survival of Islam across the European continent, Islamophobia as a concept entered into the academic and scientific discourse of the Anglo-Saxon world with the end of the Cold War. Etienne Dinet, a French scholar, used it for the first time in 1922 (Cesari, 2011, p. 21). It reappeared in an American periodical almost seventy years later, in 1991. But, it actually became popular in Great Britain and across Europe with the 1997 Report of Runnymede Commission on British Muslims and Islamophobia (Runnymede Trust, 1997). The terminology started be used more frequently by scholars and media particularly after $9 / 11$ in the USA, a means by which the debate about the place of Islam in the Western world could take place. Revisiting the concept after 20 years, the Runnymede Commission provided a longer definition to Islamophobia (Elahi and Khan, 2017, p.1):

\section{"Islamophobia is any distinction, exclusion, or restriction towards, or preference against, Muslims (or those perceived to be Muslims) that has the purpose or effect of nullifying or impairing the recognition, enjoyment or exercise, on an equal footing, of human rights and fundamental freedoms in the political, economic, social, cultural or any other field of public life."}

Along with states, international organizations also started to devote more attention to rising trends of Islamophobia. This proved especially the case in those Western European countries accommodating Muslims either as historical minority groups, migrants or refugees. Many of these Muslims now found in larger numbers in Western Europe adopted different strategies to help integrate themselves in non-Muslim majority, which may often cause a source of tension. This process of attempted integration is often reported as the source of tensions in post-Cold War Europe.

For instance, in the mid-2000s, the Organization for Security and Cooperation in Europe (OSCE) created the Personal Representative of the Chairman-in-Office of the OSCE on Combating Intolerance and Discrimination against Muslims. The idea behind this position was for the preeminent organization dealing with Europe's internal conflicts to engage in cases of antiIslamic policies or movements (OSCE ODIHR) that could harm security and unity inside the OSCE region. In the following years, it introduced the Hate Crime Reporting Mechanism through which both OSCE members and non-governmental organşizations (NGOs) has been reporting acts of Islamophobia (OSCE Hate Crime Reporting, 2021) since 2009. Furthermore, the Organization of Islamic Cooperation has also been preparing an annual observatory report on Islamophobia that charts cases from across the world since 2007 (OIC, 2021). Other organizations have also joined the struggle targeting growing anti-Muslim behavior and prejudices. In this 
respect, the Council of Europe's European Commission Against Racism and Intolerance adopted a general policy recommendation (ECRI, 2000) while various organs of the United Nations have also taken up the cause.

In the European context, it is apparent that with the rise of ultra nationalist movements across the continent, ethnic, religious and cultural minority groups started to feel more uncomfortable about their place in society. This was especially the case for both older Muslim communities and those who had recently settled in various parts of Europe. As noted in studies on minorities in Europe, Muslims are particularly affected from an increase in nationalist movement activism. Members of these rapidly growing movements are regularly documented to express their hostility towards those whose religious affiliation differs from the majority community. Drawing from this larger trend in Europe, this study deals with Islamophobia in one of the EU-member states, questioning the extent to which Islamophobia exists in Greece. As it is aptly put (Huseyinoglu and Sakellariou, 2020, p. 364) there are three main areas for reproduction of Islamophobic statements and actions in Greece that have to with immigrant and refugee Muslims, the official mosque in Athens and the historical presence of Muslim Turks in Western Thrace.

While a general problem, it is necessary to show the reader some of the main similarities and differences Muslims have in Greece, especially in respect to the limited rights of religious practice. Later, this chapter focuses on what Islamophobia means in the context of Greece and finishes with elaborating some of the main actors behind the expression of hostility toward Muslims across the country. This survey of the main Islamophobes in Greece extends to studying their roles in the construction/deconstruction of anti-Muslim sentiments, attitudes, and perceptions inside larger Greek society.

While doing so, this research argues that simultaneously there are many similarities and differences between Muslims in Greece in terms of enjoyment of religious liberties and that of getting targeted by anti-Islamic practices. The extent to which they suffer from discrimination primarily depends to which type of group of Muslims they belong. Islamophobic actions that different Muslims face in both the Greek public and private spheres is very much linked to such groupings. Furthermore, it is necessary to briefly differentiate the groups actively engaged in hostile acts toward Muslims in Greece. There are many state and non-state actors that both encourage and sometimes even discourage Islamophobic acts when targeting different groups of Muslims (a distinction often made between older and newer communities) found within Greece's borders. It is ultimately concluded after this analysis that Muslims have limited religious autonomy in Greece that is coupled with an increase in Islamophobia about which larger Greek society remains in denial,. This tgap between the Muslim and non-Muslim population in Greece actually complicates the process of integration of Muslims with the greater majority in the foreseeable future.

\section{Muslim demography in Greece}

The presence of Islam in Greece is not a new phenomenon for its citizens. To the contrary, Muslims living in what today is Greece dates back to the Ottoman administration of the Balkan Peninsula. It was in that Ottoman context that Islam flourished. Its particular success can be accounted for two main reasons: First, Islam was the primary faith of the Ottoman Empire, a composite of religious communities divided according to the Millet System (Muslims and nonMuslims) and second, the territories of contemporary Greece were Ottoman ruled from the late $14^{\text {th }}$ century until the independence of Greece in 1830. Invariably, Islam was one of the two primary religions practiced both in the old and new lands of Greece. In this respect, Greek 
exposure to Islam and practicing Muslims is not something new as it is the case in many other European countries.

The latest official figures dating back to 2011 suggests the total population of Greece is 10.816.286 (Hellenic Statistical Authority, 2014). It is unclear, however, how many Muslims are among this almost 11 million Greeks because official statistical information does not include religious affiliation. It is nevertheless safe to state that the vast majority of Greek citizens (more than 90\%) identify themselves with Orthodox Christianity, whether they practice it or not.

The importance of religion is quite robust across different segments of Greek society and this is reflected in the power of the Orthodox Church. From official openings of school years to cultural festivities, from religious oaths taken at the Parliament to the celebration of national holidays, Orthodox Christianity is quite visible across the country. Its hegemony is also safeguarded under Article 3 of the Greek Constitution: "The prevailing religion in Greece is that of the Eastern Orthodox Church of Christ". In this respect, all other faiths fall under the category of minority religions. It is estimated that Muslims outnumber all new and old minority religious groups, such as Jews, Catholics, Protestants, Jehovah's Witnesses, Old Calendarists, Mormons, Protestants. Based on some latest estimates, the size of Muslims residing in different parts of Greece (temporarily or permanently) number around 750.000 , constituting more than $5 \%$ of the Greek population (Hackett, 2016).

To reflect this relatively large presence in Greece, since the beginning of the 1990s there has emerged a growing literature in Greek about Islam and the quality of life for Muslims in Greece. Despite this now long history of scholarship about different aspects of Islam in Greece, there were almost no academic research exploring anti-Muslim hatred in the context of Greece. In this respect, the first version of this study published back in 2015 became one of the first studies dedicated to to Islamophobia in Greece. In the following years, some more appeared tackling the same issue from different perspectives (Chatzipanagiotou and Zarikos, 2019); Sakellariou, 2019). Research exploring this issue was strenghtened with annual reporting of the Ankara-based SETA foundation about Islamophobia in Europe. Since 2016, anti-Muslim hatred and bigotry in Greece has been covered on annual basis (Huseyinoglu and Sakellariou, 2020).

\section{Categorizing Muslims in Greece}

Muslims in Greece can be roughly divided into two main groups with another two subgroups drawn from each. Tsitselikis (2012) was among the first Greek scholars highlighting aspects of differentiation between the old and new Muslims in the post-Cold War Greece. The first group is composed of the older Muslims who have been living on their own historical lands for centuries. The second group we can identify as the Newcomer Muslims who make up the vast majority of those who arrived Greece in the last decades during different waves of migration.

From within the Old Muslims two ethnic Turkish groups are identifiable. Turks of Western Thrace and islander Turks of the Dodecanese, i.e. Rhodes (Rodos) and Kos (İstanköy). ${ }^{1}$ Crucially, there were far larger Muslim populations spread throughout the country prior to the Turkish-Greek Population Exchange facilitated by the League of Nations after World War I. As both Turkey and Greece agreed on peaceful swap of people, around half a million Turks left today's lands of Greece between 1922 and 1930 and resettled throughout Turkey (Hirschon 2003, pp. 13-23;

\footnotetext{
${ }^{1}$ It is useful to point out that a small number of members of this group identify their ethnic or religious identities other than Turkishness or Islam. However, this does not distort the overall picture that the vast majority of Old Muslims identify themselves with ethnic Turkish identity and Islam. Indeed, many of them prefer using triple criteria (ethnicity, religion and citizenship) for self-identification: Turk, Muslim and Greek citizen.
} 
Y1ldirım 2006). This massive exchange ultimately accounts for the demographic shifts in populations both in Greece and Turkey since 1920s.

Western Thrace, a region of consisting of 8572 square acres, hosts the only officially-recognized minority group in Greece. Being exempted from the abovementioned population exchange, Turks of Muslim faith live in all three sub regions of the region (Rhodopi (Rodop), Xanthi (İskeçe) and Evros (Meriç) and number around 140.000 based on the latest official sources dating 2011 (US International Religious Freedom Report, 2020, p. 3). The majority of Muslims are located within the Rhodopi Prefecture with the capital city of Komotini (Gümülcine).

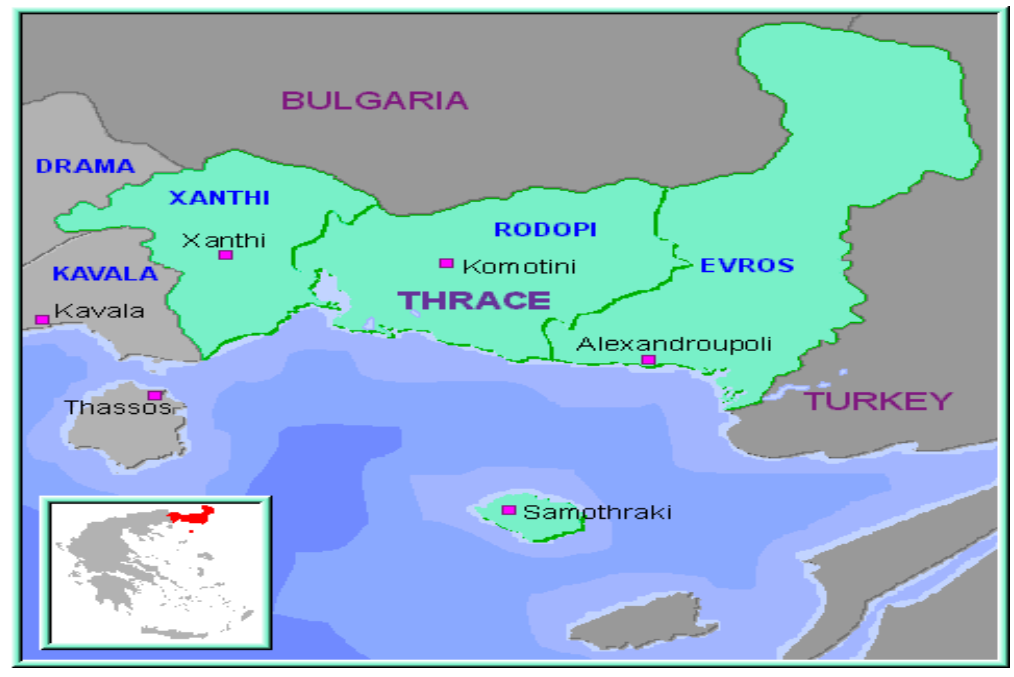

Map of Western Thrace. 2021.

Also known as the Muslim Turkish Minority of Western Thrace, people belonging to this community have been residing inside the abovementioned region for centuries. This population is one of the oldest autochthonous minority groups across Europe. Almost all members of this group belong to the Sunni Hanefi sect while there is a small number of Alevi-Bektashis living primarily in the highlands of the region close to the Bulgarian border.

Provided that this community is the only minority group that has an official minority status with the Greek state, their rights are safeguarded under the bilateral and international agreements signed between Greece and Turkey, including the 1923 Peace Treaty of Lausanne (Articles 37 45 in particular) (Lawrence, 1924, pp. 970-973). Compared to some other minority groups across the country, such as Macedonians, Greece has never questioned the very existence of a minority group in its northeastern borderlands with Turkey and Bulgaria. As for their fellow Muslims of Rhodes and Kos, these ethnic Turks became citizens of Greece in 1947 with the inclusion of Dodecanese Islands into Greek national boundaries.

For the main purpose of this research, it is useful to highlight that there are both differences and similarities between the two historical Muslim Turkish communities in terms of enjoyment of rights. As noted above, Muslims in Western Thrace have an official status of minority through which their rights (both individual and collective ones) are under protection of the international community. Those Muslims inhabiting two islands have no such a privileged status and their liberties are safeguarded only through national legislation as it is the case for all citizens of Greece. 
Another difference relates to the right of education in their mother tongue. Compared to those Muslims residing in the Rhodes and Kos Islands, Muslims of Western Thrace have always had the right to choose either a bilingual (Turkish and Greek) or monolingual public primary schooling for their own children (Huseyinoglu, 2012; Hayrullah, 2020). In the case of Rhodes and Kos, the right of primary education in their Turkish mother tongue kept provided after 1947 until the early 1972 when the last school providing bilingual education was closed by the Greek state (Kaymakç1, 2017, p. 91). Since then, Muslim Turkish children on the islands have been prevented from learning their mother language at public primary schools.

Both cases are widely interpreted as "national" or "nationally-sensitive" issues for Greece. In this respect, Greek governments have historically remained very sensitive to Turkey's relations with those Muslims living on Greek soil. Heraclides (2001, p.71) underlines that there are two main consequences for defining this issue as one of "national" importance. First, it risks being exploited by Greek governments for their own purposes. Second, the issue has historically proven to create stress and tension throughout Greek society. Aksu (2001, p.29) underlines that such issues interpreted within the rubric of "national" security also compels the Greek and Turkish majorities in each country to remain hostile toward granting any concessions to the other side.

Both Muslim groups in Greece also share some common relations with the larger Greek society. For instance, it is safe to say both groups enjoy some religious freedoms in their historic areas of residence. For instance, both groups own mosques and cemeteries that serve for their religious needs and practices. Almost all of them live peacefully in their localities shared non-Muslims without causing any significant tension based on their ethnic, religious or cultural differences. That said, however, the problems surrounding some rights of Muslim Turks are equally shared. For instance, neither of the two Muslim Turkish communities are allowed to appoint either their own religious leaders or members of their religious charitable foundations. It is the Greek government that appoints members to those seats, assuring that the state has the ultimate control over the primary religious freedoms of both communities. Moreover, the rights and liberties provided to the Old Muslims are interpreted within the principle of in situ. In case they leave their lands and start a new life in another part of the country, they then forfeit those liberties. For instance, in case a group of Muslim Turks decide to leave their historical lands and start residing in Athens or Thessaloniki, they will have no permission to construct a mosque and cannot start their own cemeteries.

New Muslims in Greece are categorized as either Immigrant Muslims or ethnic Greeks who converted to Islam. The former group constitutes the biggest proportion of Muslims in Greece; they largely arrived during or after the Cold War. In fact, Greece had turned into a country of immigration, especially from Albania, Pakistan, Bangladesh and the Middle East and North Africa (MENA) region since the early 1990s. Despite their large numbers, compared to the two other autochthonous Muslim groups mentioned above, these immigrant Muslims are continuously the most discriminated, alienated and vulnerable group. This ethnically diverse pool of primarily foreign-born Muslims suffers from the lack of even basic religious liberties. The following provides some indications of the extent of their suffering:

First, Athens has long been criticized at the local, national and international levels for being the only European capital without an official mosque. On the one hand, there are more than 300 official places of worship across Western Thrace that functions freely and meet the religious needs of Muslims numbering around 150.000. ${ }^{2}$ Similarly, the Islander Muslims (those living in Rhodes

\footnotetext{
${ }^{2}$ In the mid-1950s, the number of mosques and masjids functioning across Western Thrace had been given as 259, showing us an increase in the number of places of worship for Western Thracian Muslims (Andreadis, 1956, s.6).
} 
and Kos islands in Dodecanese) have their officially-sanctioned functioning mosques, though very limited in number (one for each island). For those Muslims living in Athens, on the other hand, even though they number at least three times those found in Western Thrace, they never had an officially sanctioned mosque built in the capital city. It took almost a century to provide an official house of worship for Muslims living in the capital city. Even though the law had passed back in 2006 (Greek Official Gazette, 2006) the official opening of the Mosque of Athens happened in fourteen years, on 2 November 2020. (Greek Ministry of Education and Religious Affairs, 2020, pp. 186-188).

Nevertheless, this study argues that it cannot go beyond having a symbolic meaning for Muslim worshippers and the Greek public. Due to its capacity limited with 350 people (both men and women), hundreds and thousands of Muslims have no other option than continue praying collectively at makeshift places of worship owned and managed by immigrants. These are often garages or apartment basements spread across different parts of Athens. In recent years, some of these places, numbering 10 as of May 2020 (Greek Ministry of Education and Religious Affairs, 2020, p.186) were legalized and given the official permission by the Ministry of Education and Religious Affairs to serve religious needs of Muslims. The rest of these sites counting around 90 should either apply to the Ministry for legalization or get closed for functioning illegally.

The second major obstacle for immigrant Muslims is the lack of graveyards. Unlike their coreligionists in Western Thrace, Rhodes and Kos, Muslim immigrants living outside of these two regions have no option to bury according to Islamic traditions since they do not own functioning cemeteries. Those who pass away have only one option for a religious funeral; corpses are transferred to Western Thrace where they get buried based on Islamic rituals. Considering these conditions, most non-native Muslims do not send the dead to their countries of origins. These often incur prohibitive costs for the family and is far more expensive than sending the deceased to Western Thrace. In the past ten years, there had been a few steps taken by Greek officials and the Greek Church so as to devote some parts of non-Muslim graveyards to construct an Islamic area. In the end, however, promises and official statements bore no fruit. Henceforth, many immigrant Muslims living primarily in Athens and different parts of the country have no ground for Islamic burial as of 2021.

Compared to immigrant Muslims, Greek converts are the least visible and numerically smallest group of Muslims in Greece. Being ethnic Greeks this group of Muslims are very fluent in the state language. In addition to their linguistic proficiency in Greek, their knowledge of Greek culture and traditions is much better than any other Muslim group in Greece. This helps them escape much of the stigmatization of other Muslims experience in Greece.

From a terminological perspective, the expression of 'Greek Muslims' fits best to this group of Muslims given that they are ethnically Greek and Muslim in terms of their choice of faith. From the three Muslim groups discussed above, there is almost no literature, either in Greek or English, about Greeks converts. The exception is the work of Sakellariou (2012) and a few articles published in Greek newspapers (Antoniadou, 2011). On the one hand, it looks like it is not an "attractive-enough" topic for the Greek media and academia compared to other types of Muslims in Greece, especially immigrants. On the other hand, Greek Muslims are not so visible and outspoken within the Greek public sphere. As a result, they are still the least known group of Muslims living primarily in urban centers of the country. 
Anna Stamou is one of the few Greek converts who speaks openly about her religious choice and sheds light on the religious matters of Muslims residing in Athens. ${ }^{3}$ As it will be clarified next, the increasing Islamophobic discourse in Greece, as it has been the case in almost all countries of Europe, precipitated the anti-Islamic rhetoric at different levels of public and private spheres. This not only broadened the gap between Muslims and Orthodox Christians, but also contributes to the alienation of both groups of Muslims feel vis-à-vis larger Greek society.

\section{Islamophobia and old Muslims}

Terminologically speaking, phobia is a term originating from the Greek language ( $\left.\varphi \beta^{\prime} \beta o \varsigma / \varphi o \beta i ́ \alpha\right)$. It means fear from somebody or something. Islamophobia has a meaning of fearing from Islam but it has many similar connotations depending on the context such as hatred towards Islam, antiMuslim racism or discrimination. This study deals with Islamophobia in Greece regarding both old and new communities separately because many of the anti-Muslim behaviors are displaced quite differently regarding both types of Muslim groups living in different parts of the country. Before digging deeper on the topic, it is essential to underscore the following argument of this research: From a wider perspective anti-Muslim hatred in Greece occurs at both physical and discursive levels and it is reproduced primarily in the realm of religion, politics and media (both printed and online) by perpetrators targeting the old and new presence of Muslims in the Greek context.

As mentioned in the beginning, Islam has a long history on the lands of Greece. In the official Greek discourse, Islam is associated with the Ottoman administration of Greece on the one hand, while affiliated with the ethnic Turkish identity on the other. In the past, both terms were widely used interchangeably so as to refer the Muslim ummah of the Ottomans as Turks. At this point, it is useful to underline that, mainly because of the negative image of Ottomans and Turks found in Greek history textbooks, both associations are quite negative among the majority of Greek people. That is to say, the Ottoman domination of today's Greece is widely perceived in Greece as a period of enslavement and subjugation. Therefore, the Greek War of Independence followed by the establishment of Kingdom of Greece in 1830 is interpreted as a new beginning for the Greek nation. Similarly, the foundation of the Republic of Turkey after the War of Independence in 1922 is considered in Greece as the "Asia-Minor Catastrophe" because it formally ended the Megali İdea, a term introduced in 1844 (Millas, 1994, 199). In other words, the beginning of the Republic of Turkey means the end of Greeks' ideal of uniting the coastal lands of the Aegean, Mediterranean and Black Seas with that of mainland Greece.

In this respect, this study emphasizes that the abovementioned zero-sum perception has not only been quite central to the bilateral relations of Greece with Turkey since the $19^{\text {th }}$ century, but also it has widely been evident in Greek government policies towards its indigenous Muslim population since 1923. In many ways, this policy is informed by the fact these Muslims are associated with an ethnic Turkish identity. ${ }^{4}$ In contrast, Greece's New Muslims come from a wide range of different ethnic backgrounds, such as Albanian, Pakistani or Arab. As a result, they primarily do not suffer from any anti-Turkish policies of Greek governments. Therefore, this study contends that one of the primary sources of bias towards Islam emanates from Greek history itself; the official discourse stipulates that the Ottomans and Turks are considered as the main "others" of the Greek nation. Thus, unlike some European countries unfamiliar with Muslims

\footnotetext{
${ }^{3}$ For a comprehensive and recent analysis about limits of religious autonomy of Muslims in Greece Huseyinoglu (2016).

${ }^{4}$ In a book dedicated to the principle of reciprocity enshrined at Article 45 of the 1923 Peace Treaty of Lausanne, the Muslim Turkish minority's position located in between the two antagonistic nationalisms (Greek and Turkish) is explained in detail (Akgönül, 2008).
} 
until recently, the historical presence of Islam in Greece not only enabled the Greek nation to learn more about the Islamic faith and Muslims, even experience is in their everyday lives, but it also proved quite the opposite: the presence of Islam in Greece triggered bias, fear and even hatred towards a religion and its followers.

Taking the abovementioned interchangeable usage of both terms, i.e. Turks and Muslim, incidents of intolerance, anger, hatred and bias towards the ethnic Turks living in Western Thrace, Rhodes and Kos has gained momentum in recent years with the rise of ultra-nationalism across Europe. The most prominent arena for this anti-Turkish display are the sacred places of these communities, such as mosques, masjids and graveyards. Attackers generally prefer to smash the windows of mosques with stones, write anti-Muslim or anti-Turkish slogans on the outside walls of mosques and plant freshly-cut pigs' heads outside of houses of worship.

Since the beginning of 2000s, such attacks have increased throughout Western Thrace. For instance, the mosque of the Isalon, a Muslim village was attacked in 2003 and 2011 and its windows were smashed with stones (WTMUGA, 2013, pp. 3-4). Toxotes, is another location that faced frequent Islamophobic attacks. It is a village where only a handful of Muslims live. Its mosque was targeted almost five times between 2004 and 2012. Some attackers smashed its windows while others aimed to set it on fire by throwing oil inside the mosque. Similar attacks, including the use of Molotov cocktails, took place in the Avato Village of the same prefecture. On 13 December 2010 the attack damaged the windows and the doors of the mosque (WTMUGA, 2011). A year before, it was reported that the entrance of the Sunne Mosque located in central Xanthi had been vandalized with anti-Turkish graffiti (US International Religious Freedom Report, 2010). The use of pig heads to desecrate Muslim places of worship has taken place on three separate occasions inside and outside of Western Thrace in recent years. Severed pigs heads were placed in front of the Halil Bey Mosque (serving as a museum) in Kavala on 3 February 2011 (Millet, 2011, p.5), the Masjid of Avantos in Alexandroupoli (Dedea ğaç) on 13 April 2014 (Millet, 2014, p.4), and the Greek-Arab Educational and Cultural Center in Athens on 17 October 2014, also, used as place of worship (Nikolouli, 2014).

In Rhodes and Kos, there are a number of mosques established under the Ottoman administration of the Dodecanese region. Yet, contrary to demands of the Islander Turks, only one mosque is open on each island for use; all the rest remain closed. From time to time, mosques are also targeted on both islands. For instance, walls of the Lonca and Cezayirli Hasan Pasha Mosque located in Kos were defamed with Islamophobic slogans (Kaymakç1, 2014). Beyond the difficulty in using undeterred the available mosques, the Greek state converted mosques into places of public access. The Süleyman Pasha Mosque, for one, was closed in 1978 but later restored and started to function as a museum while Şehitlik Mosque is used as a health center and the Mosque of Kattavia Village as a café (Kaymakçı, 2014a, 11).

From a broader framework, it is crystal clear that a majority of the Ottoman heritage that remains standing in Greece suffer from being abandoned, dilapidated and all structures in need of urgent restoration. In 2011, for instance, a part of the Recep Pasha Mosque collapsed due to lack of "effective restoration" (Dışişleri Bakanlığı, 2011$).{ }^{5}$ The following year, Greece would receive a call from the Council of Europe's PACE in this respect (Gross, 2012):

\footnotetext{
${ }^{5}$ In fact, this statement underlined that the mosque had been under restoration since the early 1990s. Nevertheless, almost no massive work had been done in the passage of more than half a decade resulting in the partial collapse of the building. As of 2020, it remained half ruined as many other Ottoman cultural heritage houses of worship in different parts of Greece. (Hatipoğlu, 2020).
} 


\begin{abstract}
"Greece is invited to continue the restoration program of Islamic and Ottoman monuments, which are an integral part of the cultural heritage of the two islands, in co-operation with Muslim associations and with all necessary respect for the integrity of the historic monuments".
\end{abstract}

Similar incidents that may be labelled a product of Islamophobia (and anti-Turkish policies) also occur in Muslim graveyards. Either tombstones are desecrated or these sites are covered with antiMuslim and/or anti-Turkish graffiti. For example, many tombstones located inside the Kahveci and Kirmahalle Muslim graveyards of Komotini were attacked in May 2010 (WTMUGA, 2011, p.2). Similarly, on $16^{\text {th }}$ of February 2012, the Poshbosh cemetery located in the same city was targeted for the third time in three years, resulting in some gravestones entirely smashed. One

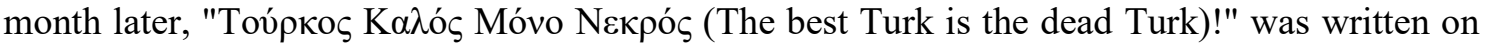
the main exterior walls of the Bektashi Tekke located in central Xanthi (WTMUGA 2013, p.3). Last year, the same expression was be used to target the elected mufti of Xanthi; it was written on the mirror of the elevator of the apartment in which he resided with mentioning his status as cleric (hodja) (Mete, 2020). In February 2014, some individuals or groups torn the Holy Quran and scattered its pages inside the main Muslim graveyard of Rhodes (İHA, 2014). A similar hatemotivated incident took place in the Islamic cemetery of Alexandroupolis in May 2019. Some tombs were defamed with Nazi symbols and some leaflets were scattered across the site with the slogan 'Greece belongs to the Greeks' (Huseyinoglu and Sakellariou, 2020, 366).

Because ethnic and religious identification is intertwined in the context of Muslim Turks of Greece, one often observes anti-Muslim bigotry and stereotyping through attacks against the ethnic Turkish identity of the Minority members. For instance, some wrote " $E \xi \omega$ or Toúpкor (Turks Out)! " on the wall of Xanthi Turkish Union in 2012 while some months later a group of Golden Down supporters throw plastic bottles and attacked verbally those Minority members sitting inside the Komotini Turkish Youth Union (OSCE, 2013). Similar examples of hatred and verbal harassment regarding Muslims of ethnic Turkish identity happened for the islander Turks of Rhodes and Kos, particularly during tensions between Greece and Turkey over the issues of Cyprus and the Aegean Sea (see Kaymakçı and Özgün, 2015, pp. 102-109).

As I have shown here, it is about both ethnic and religious identities of Old Muslims that are getting targeted frequently through hate-motivated attacks. Such incidents not only create an atmosphere of fear and anxiety for the two historical minority regimes but also it prevents any attempt of the Greek governments seeking their integration with the majority Greek society. In this respect, Islamophobia rather assists ghettoization and isolation of autochthonous Muslims, thus broadening the gap between them and those followers of the majority religion.

\title{
Islamophobia and new Muslims
}

Aspects of Islamophobia targeting New Muslims seem to remain distinct from their Western Thracian and Islander coreligionists. They rather face different forms of anti-Muslim hatred and discrimination. That is to say, no reporting about smashing of windows in mosques located in Athens is possible since there is only one official mosque opened last year. Similarly, given that there are no functioning Muslim graveyards outside Western Thrace, Rhodes and Kos no one can speak of incidents of smashed tombstones at Muslim cemeteries. ${ }^{6}$ Yet, members of New Muslims, cannot escape from Islamophobic attacks.

\footnotetext{
${ }^{6}$ To note, there are some Muslim graveyards outside Western Thrace, Rhodes and Kos that date back to the Ottoman times. But, almost all of them remained as abandoned sites and do not function for religious purposes.
} 
These immigrants are generally located in main urban centers. That said, there are also significant numbers who work at seasonal jobs in less populated regions of Greece. Estimates dating back to 2010, show that there are 82 different areas where Muslim immigrants have settled across the country (Antoniadou, 2010, p.6). These numbers have surely increased in recent years due to the arrival of new refugees from Turkey, most who crossed illegally the Aegean Sea. Since the beginning of the Syrian crisis, Greece has turned into a significant hub for those seeking to access Europe. Some years ago, it was reported that more than 56.000 refugees were living in Greece (Avgi, 2016, p.7). Unofficial estimates suggest this number is much higher.

Some of the main reasons for discrimination in Greece among these new Muslims can be attributed to some core disadvantages long responsible for Islamophobia in larger Europe. First, race is likely the biggest reason of discrimination in the Greek public sphere. Migrants' dark skin makes easy to identify for those who target the target immigrants in Greece. Second, Muslims are often stigmatized because other their name. Even if some Muslims are born and bred in main urban centers like Athens or Thessaloniki and are quite fluent in reading and/or writing in Greek, they may still face bias because of their non-Greek names. As a result, many immigrants (both Muslim and non-Muslim) prefer to adopt a Greek name. I have personally witnessed some Albanian Muslims who were called 'Ilyaz' in their villages in Albania electing to use the Greek version of it, Ilias, when trying to find work in Greece.

A similar practice of using a second name, though not so popular, is also applicable for some members of the Muslim Turkish minority who reside outside Western Thrace; they would rather use it when trying to have new friends from the Greek majority for the sake of seeking to become a part of Greek groupings. Also, it is easy to find similar examples for Islander Turks in the Dodecanese. This is another indication why names are highly crucial for accommodation of different cultures and religions inside the majority Greek society. In case they had felt comfortable enough with their primordial identities, I think that they would not opt for a second name and use it for the sake of preventing any kind of possible otherization, stereotyping and stigmatization inside the Greek society.

The third reason for being prone to discriminatory actions is their proficiency in Greek; there are many documented and undocumented immigrants living in different parts of Greece with poor fluency in Greek or not at all. One of the main criticisms raised against the language barrier is that they could not speak Greek fluently even if they had been living in Greece for a long period of time. Particularly those immigrants living in ghettos or segregated districts do not have many chances to improve their level of Greek language since many Greeks sharing the same space with them prefer not to develop contacts or friendships with immigrants. This type of social exclusion across Greece is another reason why many immigrants develop their ties with their coethnies or coreligionists rather than getting harmonized within the majority Greek society.

And the fourth main reason is about belonging to a different religion than the one of the majority. In a country of citizens the majority of whom belong to Orthodox Christianity, Islam is widely perceived and interpreted within the concept of "historical rivalry". Thus, many Greeks keep growing up with stereotypes of Islam and Muslims. Here it is primarily the Greek education system, Greek media organs and the Greek clerics who fuel negative perceptions about Islam and the Muslim world. In this context, the perception that Muslims belong to the "other" religion is one of those reasons that actually makes harder integration of Muslims with the majority Greek culture.

This study underscores that being an immigrant in Greece does not always imply being a newcomer to the country. There are many Muslim and non-Muslim immigrants who have been 
residing in Greece for decades. Some of them have already managed to get Greek citizenship through different ways such as marriage, but a number of them still live with citizenship belonging to their counties of origin, undocumented migrants or stateless people.

Before dwelling on Greek Muslim converts, this research argues that everyday life seems to be highly difficult for the vast majority of immigrants in Greece due to their status. Yet, for many Muslim members of this group, survival in Greece gets another aspect of difficulty, thus increasing the overall level of their sufferings as immigrants. That is to say, on the one hand, they need to escape from any possible xenophobic manners coming from members of the majority Greek society due to their immigrant status. While on the other hand, they may also face different types of anti-Islamic verbal-physical practices emanating from their religious preferences. Therefore, some Muslim immigrants either pretend to change their religion (especially among Albanian Muslim immigrants) while many others hide their faith to escape religious-based discrimination in Greece.

The other group of New Muslims, Greek converts, do not face many of the abovementioned problems. Interpreting the concept of Greekness through the lense of ethnic belonging but not citizenship, I prefer to refer to this group as Greek Muslims, ethnic Greeks belonging to the faith of Islam. ${ }^{7}$ It is estimated that they number around 3000 people some of whom reside abroad (Stamou, 2021). There may be different reasons for their choice of Islam. Yet, as it is noted, a spiritual search and interaction with Muslims stand as the two main factors for their conversions (Sakellariou, 2012, 73).

Their fluency in Greek and knowledge of Greek cultural practices are among those reasons why Muslim Greeks escape many kinds of religious-based discrimination coming from the majority Orthodox Christian co-ethnics. Yet, this is applicable particularly for those who prefer not to depict their religious preference openly in the public. ${ }^{8}$

Anna Stamou is the most widely-known figure of Greek Muslims in Greece. She is Marketing \& Public Relations director, and member of the Board of the Muslim Association of Greece (MAG), the main organization that is advocating for protecting the rights of the Muslims, particularly those residing in Athens and big cities. Never shy from TV programs or interviews to Greek media and international media, she has become the go-to person, a Greek woman wearing hijab. However, the image of an ethnic Greek who chose Islam and speaks fluent Greek on television is almost nonexistent. In fact, conversion stories of Greeks to Islam are rarely discussed in Greek media organs. Moreover, there are insufficient academic studies on Muslim Greek converts and their problems emanating from their choice.

Having interviewed Stamou, some points that she raised seem to be highly relevant while talking about religious liberties of Greek Muslims, ethnic Greeks of Islamic faith. For Stamou, unlike Muslim immigrants, the Greek converts need to explain only to their very close environments and sometimes even persuade them for reasons of choosing Islam. In the beginning, it is very hard for their relatives to understand those reasons of conversion. As she underlines, it is mainly being fed up with basic questions, e.g. "why do you wear hijab?", Greek converts would rather stay away

\footnotetext{
${ }^{7}$ It is crucial to keep in mind that some Greek state officials, academics and journalists use this concept while referring to different types of Muslims in Greece.

${ }^{8}$ In the past, there used to be a website called as Greeks Rethink (2014) where there were many individual stories of conversion of ethnic Greeks from Christianity to Islam in which they shared their experiences with their close relatives before and after conversion. For the last five years, the website has not accessible anymore. However, another website owned and run by Greek converts is quite popular about Islamic issues for the Greek-speaking world where there are ten different individual stories of conversion (Islam for Greeks, 2021).
} 
from their close relatives in the beginning period of their conversion. This problem that Stamou raises is not applicable to any other members of New and Old Muslims.

She also underlines class and economic aspects of Islamophobia in Greece. For Stamou, Islamophobic actions target particularly those vulnerable low class immigrant Muslims who cannot easily fight for their own rights due to their low level of Greek language and (undocumented) status inside the Greek society. It is quite difficult for them to cope with such stigmatization so they would rather ignore without making it public. Nevertheless, it is rare for a middle and upper class Muslim immigrant, who are small in number, to experience Islamophobic or xenophobic acts. In case it happens, she/he knows how to respond and claim justice before the Greek courts.

As for the economic aspect, Stamou aptly emphasizes that Islamophobia grew with the deepening economic crisis and degrading governmental policies that followed in recent twelve years. The rise of Islamophobia corresponds with increasing racism and xenophobia within the Greek society along with the systematic degrading of the Muslim communities, indigenous and not, all over Europe as an ultra-right political movement that is being adopted gradually by most EU countries. With a few exceptions, many Greek Muslims prefer to hide their individual choices of conversion due to the certainty of getting stigmatized in their working environments, or even academic careers, likely to result in otherization, discrimination and finally losing their jobs, or denied access in the first place, especially if they wish to follow an army or police or justice career. This pragmatist approach indicates that converting to Islam, taking a Muslim name or wearing hijab still contain high risk of losing or changing profession. Therefore, it stands as a rational choice for many Greek Muslims to hide their religious preference in public and make it visible only inside their families (Stamou, 2021).

Before finishing this section, it is useful to underline one of the most significant aspects of Islamophobia in Greece. Looking closer at hate motivated Islamophobic attacks, it becomes obvious that many of the perpetrator(s) remain unidentified. Based on the OSCE's Hate Crime Reporting Data, the overall numbers of hate crimes recorded officially by the Greek police counts as 573 for the period between 2012 and $2018^{9}$. Only 135 of cases were prosecuted 22 of which were sentenced under the Greek law (OSCE, 2021). Given that the level of punishment remains so low, hate motivated attacks against Muslim and non-Muslims of the society are not likely to diminish in the near future.

\section{Actors of Islamophobia}

While focusing on different aspects of Islamophobia in Greece, this study has identified four main perpetrators of Islamophobia in the Greek context: The first is the Greek state itself. For many years after the end of Cold War, Greece - governed either by rightwing or leftwing political parties such as Pasok, New Democracy or Syriza - applied different policies towards the integration of immigrant groups primarily residing in Athens. Yet, there has never been a consistent policy towards their accommodation inside the Greek society. None of the governments have effectively spent effort to find solutions to fundamental problems that immigrants face in their everyday lives. Meanwhile, core religious liberties of Old Muslims have also remained restricted. As of 2021, for instance, no step has been taken by the Greek state to return the rights to Western Thracian and Islander Muslims to choose their own religious leaders. Similarly, the problems Muslim Greeks converts face have usually been ignored by the Greek state apparatuses. In this respect, ignorance

\footnotetext{
${ }^{9}$ It is unavoidable that those numbers increase when the unrecorded attacks provided by various NGOs located in Greece are also included in the list of the OSCE Hate Crime mechanism. Its website provides both official figures provided by Greek officials as well as those provided by local NGOs and human rights organizations.
} 
is the accurate term that can be used for Greece's tackling of discriminatory anti-Muslim issues across the country provided that many problems of Muslims in Greece still keep falling on deaf ears of the MPs inside the Greek Parliament and officials-decision makers of the Greek state as of 2021.

The second main perpetrator of Islamophobia in Greece has to do with the Greek political sphere. Above all, the most prominent example in the past was the Golden Dawn Party. Reinforced primarily by increasing trends of racism across Europe and deepening of economic crisis, the party secured a broad base of supporters from within the Greek society and eventually won seats in the Greek Parliament. Thus, their ultra-nationalist, racist, xenophobic and Islamophobic statements and actions started to get heard louder from the highest level of Greek politics. For instance, Golden Dawn had launched campaigns in 2012 that aimed to help exclusively those of ethnic Greek origin in need for food, clothes and shelter (Protho Thema, 2012). At the same time, it launched several anti-Muslim and racist campaigns against Muslims living in Athens. The most popular of them had targeted the construction of an official house of worship that had a history going back to the 1880s. ${ }^{10}$ Even though Golden Dawn's 'No Mosque in Athens' campaign resulted in repeating many criticisms coming from Greek citizens, such efforts were ultimately defeated by the determination of the SYRIZA-ANEL Coalition Government coupled with Muslim NGOs' unabated demands for an official mosque (Tsiropoulou, 2017). As a result, it was opened last year under the leadership of the new government in Greece, Kiriakos Mitsotakis-lead New Democracy. To note, Golden Dawn had also blamed several times, even under the premises of the Greek Parliament, those Muslim Turkish minority MPs, regardless of their party affiliations, as "agents" of Turkey and/or the President Recep Tayyip Erdoğan.

Some clergymen members of the highest religious authority of the country, the Greek Orthodox Church, constitute another group of perpetrators of Islamophobia in Greece. The Church is quite influential in different spheres of aspects of the religious, social and cultural lives of Greek citizens. Statements coming from this institution and regional bishops have always been effective in perceptions about minority religions in Greece across different segments of the Greek society. As the highest religious institution of the country, the Greek Orthodox Church refrains from using any kind of anti-Islam rhetoric about issues of Muslims living across the country. Nevertheless, it fails to prevent some of its members' Islamophobic statements. That is to say, some figures of the Greek Church, those either based in Athens or peripheral areas of the country, prefer to express their own anti-Islamic opinions or use anti-Muslim discourses openly independent from the Greek Church inside or outside of the churches they serve.

The Mosque in Athens turned out to be one of the most-frequently discussed topics among clerics. In fact, the Orthodox Church has never rejected the right of Muslims to have an official house of prayer in Athens. However, some Metropolitan Bishops, like that of Seraphim from Piraeus or Anthimos from Thessaloniki, openly expressed their opposition to the construction of Islamic places of worship in Greece. "Islam is a destructive faith" quotation is from one of his latest interviews at a Greek television in late January 2017 (Orthodoxia Online, 2017).

Similarly, Damaskinos (1996, p. 21), the local Metropolitan Bishop based in Komotini back in the 1990s, had claimed that many religious events organized by Muslims "disturbed and even challenged" the local Orthodox Christian population. Another book printed by the same local church blamed Muslim clerics for distributing Turkish propaganda during religious activities either inside or outside houses of prayer (Damaskinos, 1989, p.21). Until his death in 2012, a

${ }^{10}$ For a detailed research of this topic see Triandafyllidou and Gropas (2009). 
number of controversies had taken place between Damaskinos and many leading figures of the Muslim Turkish minority in respect to religious autonomy in Western Thrace.

Media, both electronic and printed, is the last major perpetrator of Islamophobia is Greece. Some journalists and certain media organs adopt an over Islamophobic discourse covering issues about Muslims in Greece. Some of the Greek mass media associate Islam with extremism and religious fundamentalism. ${ }^{11}$ From time to time, Islam in Greece is questioned after some terrorist attacks in different parts of Europe. Along with the houses of worship, Islamic headscarf worn by Muslim students at National Parades (25 collectively in large numbers at places provided by the Greek state, such as some stadiums in Athens, are some of the common instances where Greek media diverts its attention to debates about the limits of Islam in the Greek public sphere (Eleftheros Typos, 2016).

Yet, of all other matters regarding Islam, the construction of a mosque in Athens turned out to be the most widely-covered issue by the Greek media which contributes triggering the whole debate about Islam inside the Greek society. In this respect, discussions presented through Greek media about the religious rights of Muslims in Greece directly affect construction and deconstruction of image about Islam in the minds of Greek citizens at various levels and segments.

\section{CONCLUSION}

This study has underscored that there are many similarities and differences in terms of rights enjoyment of Muslims living in different parts of Greece. Members of the historical Muslim Turkish minority in Western Thrace enjoy more religious liberties than all other Muslims. Being the only officially recognized minority group in Greece, their rights emanating from their minority statushood is safeguarded under the Greek and international law. The Islander Muslim Turks also have some primary religious rights though less than their co-ethnies in Western Thrace. Still, Muslim immigrants compose the most vulnerable group of Muslims whose rights and liberties are kept at the minimum level as a result of different policies of the Greek governments. Being the smallest group in number, ethnic Greeks who converted to Islam have their own problems in respect to their religious liberties.

Along with their rights suffering emanating from belonging to a minority faith, Muslims in Greece do also face a variety of Islamophobic actions in their everyday lives. It is almost impossible for many of them to escape from anti-Muslim actions or hate-motivated statements coming from nonMuslim members of the Greek society. Of all, only a small proportion of Muslims tries to find justice before the Greek law while many others just ignore any kind of demonization, stigmatization or discrimination they face based on their Islamic identity. It is apparent that economic crisis in Greece back in 2010 and its reflections up until recently fueled extreme nationalism, xenophobia and racism among Greeks, thus accelerating the overall pace of Islamophobia towards any kind of Muslim group residing across the country.

Re-examining Islamophobia in Greece after almost half a decade when the first version of this article appeared, it can be concluded that aspects and actors of Islamophobia haven't changed so much even though anti-Muslim hatred displayed at physical level, such as targeting of the mosques or Islamic graveyards, have decreased in recent years while it is the opposite at the discursive level; anti-Muslim hate speech has recently been growing at public spheres and printed-

\footnotetext{
${ }^{11}$ For a variety of the most recent examples about Islamophobic statements at the Greek printed and online media organs for the year 2019 see (Huseyinoglu and Sakellariou, 2020, pp. 375-378).
} 
electronic media under the rubric of the so-called "Islamization" of Greece. However, one of the most prominent agents for reproduction of anti-Islam rhetoric at Greek politics, the far-right Golden Dawn, was dissolved last year when the Greek court, after long-running trials, finally ruled it as a criminal organization (Panoutsopoulou, 2020).

From a wider perspective, this study has confirmed that phobia is not always directed at something unknown or alien. Historical knowledge, as in the case of Old Muslims in Greece, may actually trigger negative sentiments as well. At this point, perpetrators of Islamophobia come to the forefront. As emphasized above, there are many different state and non-state actors perceiving and portraying Islam in Greece negatively. While Islamophobic actions are seldom persecuted, many of perpetrators keep to remain unidentified. The Greek print and online media generally refrains from covering issues about discriminations or hatred against Muslims living in different parts of the country. Henceforth, the result may likely be that the growing trend of Islamophobia in various segments of Greek public and private spheres is likely to continue in the third decade of the millennium.

To conclude, it seems urgent for the Greek state to take action to fight Islamophobia inside the Greek society. Any kind of anti-Islam discourse demonizing, otherizing or discriminating Muslims should strongly be discouraged by Greek officials functioning at both local, regional and national levels. For this sake, those insisting on their Islamophobic statements or actions should be prosecuted and eventually sentenced regardless of their public identities or statuses in the society, e.g. clerics, politicians, MPs.

As for some future prospects of this research topic, this research contends that Greece needs to establish a state-led mechanism to fight Islamophobia at different levels of the society. The effectiveness of such an action will also depend on the inclusion of Muslims in decision-making processes about those issues that has to do with Islam in Greece; being in close collaboration with all four main type of Muslims will be imperative for the main purpose of this mechanism. Otherwise, as the history of the poor treatment of minorities in Greece indicate, none of those unilateral actions taken by non-Muslim members of the Greek majority will adequately address and solve problems of growing anti-Muslim practices in Greece.

\section{REFERENCES}

Akgönül, S. (Ed) (2008). Reciprocity Greek and Turkish Minorities: Law, Religion and Politics. İstanbul: İstanbul Bilgi University Press.

Aksu, F. (2001). Türk-Yunan İlişkileri. Ankara: SAEMK.

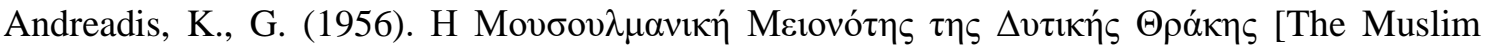
Minority of Western Thrace]. Thessaloniki: IMXA.

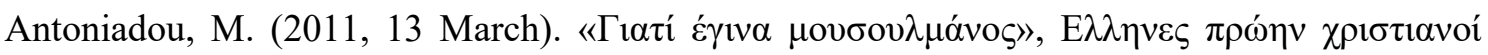

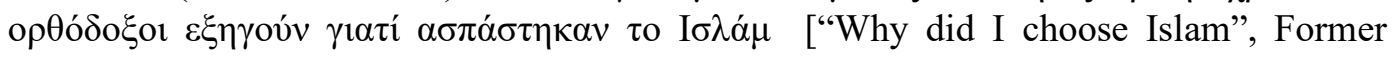
Orthodox Christian Greeks tell why they chose Islam], To Vima, p.7.

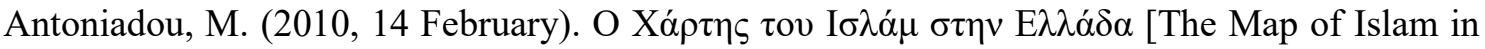
Greece]". To Vima, p.5.

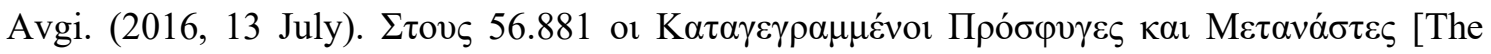
number of Recorded Immigrants and Refugees is 56.881]. 
Cesari, J. (2011). Islamophobia in the West: A Comparison Between Europe and the United States. John S. Esposito and Ibrahim Kalın (Ed.) In Islamophobia, The Challenge of Pluralism in the 21st Century (pp. 21-46). Oxford: Oxford University Press.

Chatzipanagiotou, M. and Zarikos, I. (2019). Countering Islamophobia in Greece. Ian Law, Amina Easat-Daas, Arzu Merali, Salman Sayyid (Ed.). In Countering Islamophobia in Europe (pp. 79-122). Cham, Switzerland: Palgrave MacMillan.

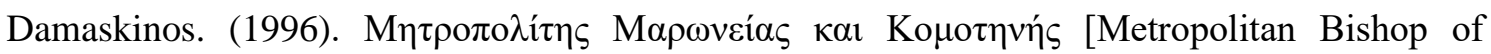

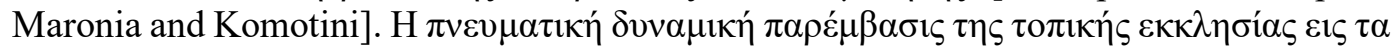

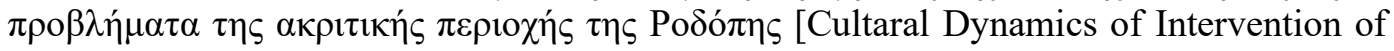
the Local Church regarding problems of the Border Area of Rhodopi]. Komotini, 1996.

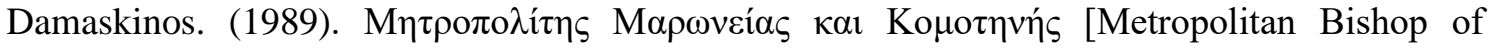

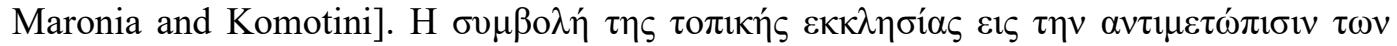

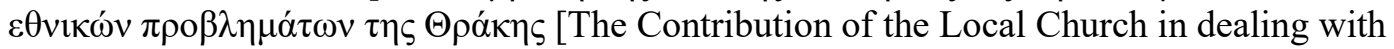
of the national problems of Thrace]. Komotini: Iera Mitropolis Maronias kai Komotinis.

Dışişleri Bakanlığı. (2011, 23 Aralık). Bakanlık Açıklaması No:309, Yunanistan'daki Recep Paşa Camii Hk. Retrieved from http://www.mfa.gov.tr/no 309 -23-aralik-2011 yunanistan_daki-recep-pasa-camii-hk_tr.mfa.

ECRI. (2000). General Policy Recommendation No. 5. 2000. Retrieved from https://rm.coe.int/ecri-general-policy-recommendation-no-5-on-combating-intoleranceand-d/16808b5a76

Elahi, F. and Khan, O. (Ed.) (2017). A 20 ${ }^{\text {th }}$ Anniversary Report, Islamophobia, Still a Change for us All. Retrieved from https://www.runnymedetrust.org/uploads/Islamophobia\%20Report\%202018\%20FINAL. pdf

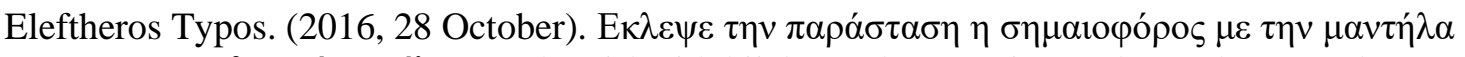
$\sigma \tau \eta \nu \mu \alpha \theta \eta \tau \imath \kappa \eta ́ ~ \pi \alpha \rho \varepsilon ́ \lambda \alpha \sigma \eta$ [The girl with hijab got the attention at the student parade]. Retrieved from https://eleftherostypos.gr/ellada/47887-eklepse-tin-parastasi-isimaioforos-me-tin-mantila-stin-mathitiki-parelasi/.

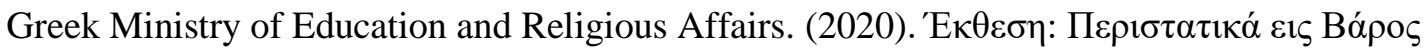

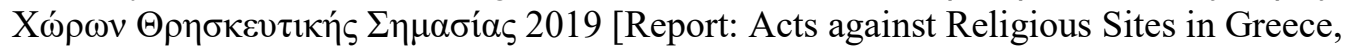
2019]'. Retrieved from https://www.minedu.gov.gr/gepo-menu-m/ekthesi-peristatika-eisvaros-xoron-thriskeftikis-simasias.

Greek Official Gazette. (2006, 5 December). FEK A’264.

Greeks Rethink. (2014, 12 January). Retrieved from www.greeksrethink.gr

Gross, A. (2012, 9 March). The situation of the Greek citizens of Turkish descent in Rhodes and Kos. Council of Europe's Committee on Legal Affairs and Human Rights. Resolution 1867. Retrieved from https://pace.coe.int/en/files/18075\#trace-3.

Hackett, C. (2017, 29 November) 5 facts about the Muslim population in Europe. Retrieved from http://www.pewresearch.org/fact-tank/2016/07/19/5-facts-about-the-muslimpopulation-in-europe/. 
Hatipoğlu. M. (2020, 10 Haziran). Yunanistan'daki Türk-İslam eserlerinin büyük çoğunluğu yıllardır amacı dişında kullanılıyor. Retrieved from https://www.aa.com.tr/tr/dunya/yunanistandaki-turk-islam-eserlerinin-buyuk-cogunluguyillardir-amaci-disinda-kullaniliyor/1871730.

Hayrullah, P. (2020). Balkan Savaşlarından Sonra Batı Trakya Türklerinin Sosyo-Kültürel Hayat ve Eğitim Tarihi. Gümülcine: BAKEŞ Yayınları.

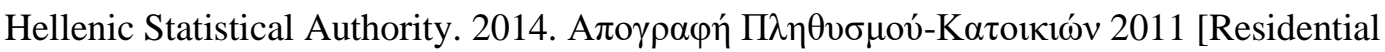
Census 2011]". Retrieved from https://www.statistics.gr/2011-census-pop-hous.

Heraclides, A. (2001). Yunanistan ve “Doğu'dan Gelen Tehlike” Türkiye. İstanbul: İletişim.

Hirschon, R. (2003). Consequences of the Lausanne Convention: An Overview'. Renee Hirschon (Ed.). In Crossing the Aegean: An Appraisal of the 1923 Compulsory Population Exchange between Greece and Turkey (pp. 13-23). New York; Oxford: Berghahn Books.

Huseyinoglu, A. (2012). The Development of Minority Education at the South-easternmost corner of the EU: The Case of Muslim Turks in Western Thrace, Greece. (Unpublished doctoral dissertation). University of Sussex / Department of International Relations, Brighton.

Huseyinoglu, A. and Sakellariou, A. (2020). Islamophobia in Greece: National Report 2019. Enes Bayraklı and Farid Hafez (Ed.) In European Islamophobia Report 2019 (pp. 357-383). Istanbul: SETA.

Hüseyinoğlu, A. (2016). Islam and Religious Liberties in Western Thrace, Greece. Muhammet Savaş Kafkasyalı (Ed.). In Islam in the Balkans: Unexpired Hope (Vol.4: From Times of Glory to Times of Humility) (pp. 141-158). Ankara: T.C. Başbakanlık Türk İşbirliği ve Koordinasyon Ajans1.

Interview with Anna Stamou (over Skype), May 11, 2021.

Islam for Greeks. (2021, 10 May). Retrieved from , http://islamforgreeks.org/.

İHA. (2014, 24 February). Rodos'taki Müslüman Mezarlığına Çirkin Saldırı. Retrieved from http://m.iha.com.tr/haber-rodostaki-musluman-mezarligina-cirkin-saldiri-335063/.

Kaymakçı, M. (2017). Rodos ve İstanköy Türklüğü Ansiklopedisi. İzmir: Rodos ve Onikiada Türkleri Kültür ve Dayanışma Derneği Yayınları.

Kaymakçı, M. (2014, 27 Eylül). Ege'nin Unutulan Rodos Ve İstanköy Türkleri. Retrieved from https://www.star.com.tr/ege/egenin-unutulan-rodos-ve-istankoy-turkleri-haber-945096/

Kaymakçı, M. (2014a). Current Problems and Solutions Concerning Turkish Identity in Rhodes and Kos. Mustafa Kaymakçı and Cihan Özgün (Ed.). In Turkish Identity in Rhodes and Kos (3-24). İzmir: Rhodes and Kos and the Dodecanese Islands Turks Culture and Solidarity Association.

Kaymakçı, M. and Özgün, C. (2015). The Recent History of the Rhodes and Kos Turks. İzmir: Rhodes and Kos and the Dodecanese Islands Turks Culture and Solidarity Association. 
Lawrence, M. (1924). The Treaties of Peace, 1919-1923 (Vol.2). New York: Carnegie Endowment For International Peace.

Map of Western Thrace. (2021). Retrieved from http://www.maps-of-greece.com/thracemap.htm.

Mete, A. (2020). Twitter (@muftu_ahmetmete), Retrieved from https://twitter.com/muftu ahmetmete/status/1332382039304249347

Millas, H. (1994). Yunan Ulusunun Doğuşu. İstanbul: İletişim.

Millet. (2011, 10 February). Cami Girişine Domuz Baş1 Asıldı. Millet Gazetesi (İskeçe). p.7.

Millet. (2014, 17 February). Dedeağaç’ta Mescide Domuz Başı ile Çirkin Saldırı. p. 5.

Nikolouli, S. (2014, 2 June). Pig's head, hate slogans at Athens Muslim center. Retrieved from http://greece.greekreporter.com/2014/10/17/pigs-head-hate-slogans-at-athens-muslimcenter/.

OIC. (2021). Islamophobia Observatory. Retrieved from https://www.oicoci.org/page/?p id=182\&p ref=61\&lan=en.

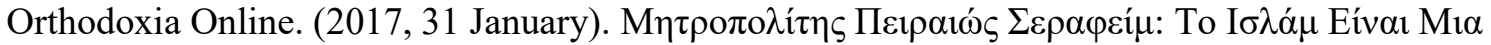

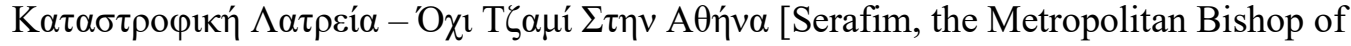
Pireaus: Islam is a catastrophic Religion- No Mosque in Athens]. Retrieved from https://cutt.ly/YbSCSay.

OSCE ODIHR. Office for Democratic Institutions and Human Rights. Countering Discrimination Against Muslims. Retrieved from http://www.osce.org/odihr/countering-discriminationagainst-muslims.

OSCE. (2013, 15 November). Hate Crimes in the OSCE Region - Incidents and Responses: Annual Report for 2012. Retrieved from http://tandis.odihr.pl/hcr2012/

OSCE. (2021). Hate Crime Reporting, Greece. Retrieved from https://hatecrime.osce.org/.

Panoutsopoulou, M. Greece: Far-right Golden Dawn found to be criminal group. Retrieved from https://www.aa.com.tr/en/europe/greece-far-right-golden-dawn-found-to-be-criminalgroup/1998588

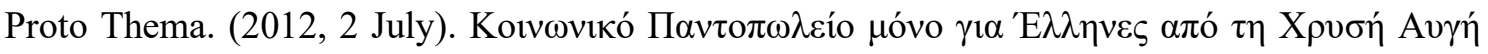
[Social aid from Golden Dawn only for Greeks. Retrieved from http://www.protothema.gr/greece/article/208102/koinoniko-pantopoleio-mono-giaellhnes-apo-th-xrysh-aygh-

Runnymede Trust. (2017). Islamophobia, A Change for Us All. Retrieved from https://www.runnymedetrust.org/companies/17/74/Islamophobia-A-Challenge-for-UsAll.html.

Sakellariou, A. (2019). Islamophobia in Greece, The 'Muslim threat' and the panic about Islam. Irene Zempi and Imran Awan (Ed.). In The Routledge International Handbook of Islamophobia (198-211). Abington: Routledge. 
Sakellariou, A. (2012). From Greek Orthodoxy to Islam: Conversion in Contemporary Greek Society and Public Self-Representation. Journal of Muslims in Europe, 1 (1), 59-80.

Triandafyllidou, A. and Gropas, R. (2009). Constructing Difference: The Mosque Debates in Greece. Journal of Ethnic and Migration Studies, 35 (6), 957-975.

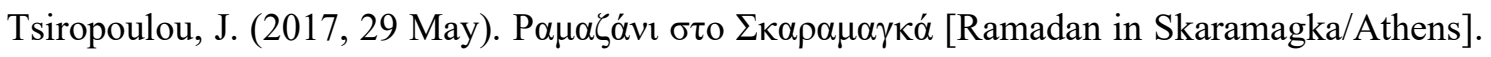
The Press Project. Retrieved from https://www.thepressproject.gr/article/111915/Ramazani.

Tsitselikis, K. Old and New Islam in Greece: From Historical Minorities to Immigrant Newcomers. Leiden; Boston: Martinus Nijhoff.

Yıldırım, O. (2006). Diplomacy and Displacement: Reconsidering the Turco-Greek Exchange of Populations, 1922-1934. New York; London: Routledge.

US International Religious Freedom Report. (2010, 17 November). 2010 Report on International Religious Freedom. US Bureau of Democracy, Human Rights, And Labor. Retrieved from https://www.state.gov/j/drl/rls/irf/2010/148940.htm.

US International Religious Freedom Report. (2020). Greece 2020 International Religious Freedom Report. US Department of State, Office of International Religious Freedom. Retrieved from https://www.state.gov/reports/2020-report-on-international-religiousfreedom/greece/.

WTMUGA. (2013, 25 September). Combating intolerance and hate-motivated attacks against the Muslim Turkish Minority of Western Thrace in Greece. Written Contribution by the Western Thrace Minority University Graduates Association. OSCE Human Dimension Implementation Meeting, 23 September - 4 October 2013, Warsaw, Poland. HDIM.NGO0127/13.

WTMUGA. (2011, 4 October). The Examples of Hate Crimes in Western Thrace. Written Contribution by the Western Thrace Minority University Graduates Association. OSCE Human Dimension Implementation Meeting, 26 September - 7 October 2011, Warsaw, Poland. HDIM.NGO/0372/11. 